\title{
Medicinal Plants used in the Treatment of Hepatitis in Bobo- Dioulasso: Studying the Availability and Analyzing the Phytochemical Properties of Combretum micranthum G. Don and Entada africana Guill. et Perr.
}

\section{Dakio Bernice,}

Université Nazi Boni, Unité de Formation et de Recherche en Sciences et Techniques (UFR-ST), Département de Sciences biologiques, Bobo-Dioulasso, Burkina Faso

\section{Bangou Mindiédiba Jean,}

Laboratoire de Biochimie et de Chimie Appliquées (LA.BIO. C. A), U.F.R/ S.V.T, Université Joseph KI-ZERBO de Ouagadougou, Burkina Faso. Unité de Formation et de Recherche en Sciences et Techniques (UFR-ST), Département de Biochimie Microbiologie, Université Nazi Boni,

Bobo-Dioulasso, Burkina Faso

\section{Ouoba Paulin,}

Ouoba Yempabou Hermann,

Université Nazi Boni, Unité de Formation et de Recherche en Sciences et Techniques (UFR-ST), Département de Sciences biologiques, Bobo-Dioulasso , Burkina Faso. Université Joseph Ki-Zerbo, Unité de Formation et de Recherche en Sciences de la Vie et de la Terre (UFR-SVT), Laboratoire de Biologie et Écologie Végétale (LABEV), 03 BP 7021 Ouagadougou 01, Burkina Faso

\section{Guenné Samson,}

Laboratoire de Biochimie et de Chimie Appliquées (LA.BIO. C. A), U.F.R/ S.V.T, Université Joseph KI-ZERBO de Ouagadougou, Burkina Faso

\section{Meda Roland N.T.,}

Laboratoire de Biochimie et de Chimie Appliquées (LA.BIO. C. A), U.F.R/ S.V.T, Université Joseph KI-ZERBO de Ouagadougou, Burkina Faso. Unité de Formation et de Recherche en Sciences et Techniques (UFR-ST), Département de Biochimie Microbiologie, Université Nazi Boni,

Bobo-Dioulasso, Burkina Faso

Zangré Abdoul Kader,

Ecole Nationale des Eaux et Forêts/Dindérésso, Bobo-Dioulasso, Burkina Faso 


\section{Tiendrebeogo Romaric,}

Université Nazi Boni, Unité de Formation et de Recherche en Sciences et Techniques (UFR-ST), Département de Sciences biologiques, Bobo-Dioulasso, Burkina Faso

\section{Anicet Georges Ouédraogo,}

Unité de Formation et de Recherche en Sciences et Techniques (UFR-ST), Département de Biochimie Microbiologie, Université Nazi Boni, Bobo-Dioulasso, Burkina Faso. Laboratoire de Recherche et d'Enseignement en Santé et Biotechnologies Animales (LARESBA), Université Nazi Boni, Bobo-Dioulasso, Burkina Faso

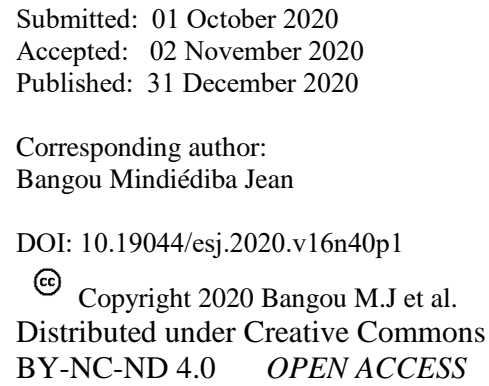

\section{Abstract}

This paper focuses on studying the inventory of the medicinal plants used in hepatitis care in Bobo-Dioulasso and evaluating their availability in local vegetation and their phytochemical properties. To achieve this objective, several approaches were developed which include: (1) an ethnobotanical survey among 111 traditional health practitioners (THP); (2) a dendrometric study to evaluate the abundance and spatial distribution of these species in Dindérésso Classified Forest; and (3) an evaluation of polyphenolic compounds and antioxidant activity of the two most quoted species roots using three methods such as anti-DPPH*, anti-FRAP, and antiABTS. The results show that Entada africana and Combretum micranthum were the most quoted species among 40 species used in the treatment of liver disease. The availability study revealed that juvenile and adult individuals of E. africana are frequent in woody savannah, shrubby savannah, and grassy savannah. As for juvenile and adult $C$. micranthum individuals, they are only frequent in wooded savannah $(\mathrm{RI}<60 \%)$. These populations are therefore declining due to anthropogenic pressure. Phytochemical analysis reveal polyphenols contents of 37.91 and $20.71 \mathrm{mg}$ EAG/100 $\mathrm{mg}$ respectively for $C$. micranthum and $E$. africana and flavonoids contents of $0.85 \pm 0.09$ and $0.66 \pm 0.05 \mathrm{mg} \mathrm{EQ} / 100 \mathrm{mg}$ respectively for $C$. micranthum and E. africana. Finally, the results show that there is an anti-oxidant activity for the two species. There were about 198 and $13 \mu \mathrm{mol} \mathrm{EAA} / \mathrm{g}$ for the two species i.e., 
ABTS and DPPH, respectively. The results show that the antioxidant activity could partially justify the traditional use of this plant.

Keywords: Hepatitis, Ethnopharmacology, Traditional medicine, Phytochemistry

\section{Introduction}

Liver disease or hepatitis is a major global public health problem (WHO, 2016). The most crucial are viral and alcoholic hepatitis according to the World Gastroenterology Organization (WGO, 2012). Viral hepatitis is the most common and widespread hepatitis in the world (Guinnin et al., 2015). According to the Francophone alliance of health actors in the fight against HIV and chronic viral infections, they are more dreadful than the three major pandemics (HIV, tuberculosis and malaria) in terms of the number of infections and deaths they cause (AFRAVIH, 2018). Worldwide, about 328 million people are infected annually and 1.4 million people die annually from these viral hepatitis infections (WHO, 2016). In Africa, about 19 million people are infected by hepatitis $\mathrm{C}$ virus and 75 million people suffer from hepatitis B, including 1.9 million people in Burkina Faso (WHO, 2016; Meda et al., 2018). Although these diseases are treated by modern medicine, people still resort to traditional medicine for their cure (Sourabié et al., 2012).

According to the Centre for Economic and Social Policy Analysis (CAPES, 2004), 90\% of the Burkinabè population uses traditional medicine and pharmacopoeia for treatment. This is because of the country's inadequate health and pharmaceutical coverage and the inaccessibility to modern treatments by financially deprived populations (Zerbo et al., 2007). Ethnobotanical and pharmacognosic research is needed to document and thus perpetuate this traditional knowledge of health management using local plants. In this context, various scientific works on hepatoprotective plants have been undertaken. Some have covered Africa (Bitsindou et al., 1993), while others have focused on smaller areas in the sub-region such as Benin and Mali (Sangaré, 2005; Sangaré et al., 2012; Guinnin et al., 2015). However, in Burkina Faso, few studies have been conducted on these medicinal plants used in the traditional treatment of liver diseases. Also, plants natural antioxidants have the property to trap free radicals produced in excess due to the attack of liver cells by viruses, thus limiting and/or repairing liver damage (Twedt, 2006). Hence, the interest in evaluating the natural substances of medicinal plants traditionally used against hepatitis has grown significantly.

Moreover, the craze for plants, combined with the lack of official texts regulating the collection of medicinal plants, increase the pressure on 
vegetation. In addition, the fragility of the ecological balance requires that particular attention should be paid to the rational management of renewable natural resources, in general, and medicinal species in particular (Yelkouni, 2004). Therefore, in addition to ethnobotanical and pharmacognosic work, investigations must be carried out on the diagnosis of the state of the populations of these medicinal species for their sustainable management. The general objective of this study is to contribute to the knowledge of plants used in hepatitis treatment by evaluating photochemistry properties and their availability. Specifically, it is about:

- inventorying the medicinal species used in the hepatitis treatment by the traditional health practitioners of Bobo-Dioulasso,

- determining the availability of these species in the Dindérésso classified forest,

- measuring the total polyphenols and flavonoids of the two species and their antioxidant power.

\section{Material and Methods}

Plant Material: The roots of Entada africana and those of Combretum micranthum were harvested in October 2019 in the classified forest of Dindérésso (Bobo Dioulasso). Also, it was identified in the Laboratory of Biology and Plant Ecology of the Nazi BONI University (NBU). They were firstly washed and dried in the chemistry laboratory (room temperature), and made into powder. This activity was carried out in the Laboratory of Research and Teaching in Animal Health and Biotechnology (LARESBA).

Solvent and Reagents: The solvents used are analytical grade methanol and distilled water. The reagents are: DPPH (1,1-diphenyl-2picrylhydrazyl), phosphate buffer, potassium hexacyanoferrate $\left[\mathrm{K}_{3} \mathrm{Fe}(\mathrm{CN})_{6}\right]$, trichloroacetic acid, trichloroferrate $\left[\mathrm{FeCl}_{3}\right]$, potassium persulfate, ABTS (2,2'-azinobis-[3- ethylenzothiazoline-6-sulfonic acid]) for evaluation of antioxidant activity, and Follin-ciocalteu and sodium carbonate $\mathrm{AlCl}_{3}$ (aluminum chloride) for the determination of total phenolics and flavonoids.

Extraction: A mass of $15 \mathrm{~g}$ of vegetable powder from each sample was weighed and loaded into extraction cartridges and placed in a Soxhlet. A volume of $200 \mathrm{~mL}$ of methanol was placed in the extraction flask and the temperature was maintained at $70^{\circ} \mathrm{C}$. This operation lasted at least 4 hours for each sample. After then, the extract was concentrated and placed in empty petri dishes previously labelled and weighed. The crude extracts thus obtained were then placed in the open air to evaporate the solvent and produce a dry residue.

Medicinal Plants Inventory: The ethnobotanical survey was used to select the two most quoted species on which availability and phytochemistry 
studies were conducted. For the ethnobotanical survey, we used ethnobotanical survey sheets to collect the different information from the interviewees. This survey was carried out on four (4) groups of traditional health practitioners in the city of Bobo-Dioulasso, namely: the Provincial Association of Traditional Practitioners of "Houet" (Group 1), the Association of Traditional Practitioners and Herbalists (Group 2), the Association of Dozos of "Houet" (Group 3), and the National Federation of Traditional Practitioners of Bobo Dioulasso (FENATRAB) (Group 4). We interviewed the Traditional Health Practitioners, having agreed to answer our questions, and having at least ten (10) years of experience in the use of plants in traditional medicine and pharmacopoeia. The approach used was the semistructured interview in the local language Dioula. The data collected covered their knowledge of hepatitis, the names and parts of the plants they use to treat hepatitis, and their years of experience as a Traditional Health Practitioners. For species identification, several flora were used (Maydell, 1992 ; Arbonnier, 2000 ; Guinko, 2009).

Availability: At the end of the ethnobotanical surveys, the two most quoted species were selected and their abundance was evaluated in the Dindérésso Classified Forest (Figure 1). Dindérésso Classified Forest is a natural reserve near Bobo-Dioulasso with a significant floristic potential. The stratified random sampling inventory method was adopted. Indeed, this method has several advantages, including the possibility of all vegetation units to be sampled. The dendrometric inventories of the selected species were carried out during the month of December 2019. Data collection plots were installed in the different plant formations. The size of the plots we used is $900 \mathrm{~m}^{2}(30 \mathrm{~m} \times 30 \mathrm{~m})$. It was used by Ouédraogo et al. (2009), Bognounou et al. (2009), and Sop et al. (2010). Diameter measurements of trees were made at chest height (DBH), i.e., at $1.30 \mathrm{~m}$ above ground level for trees using the forest compass. 


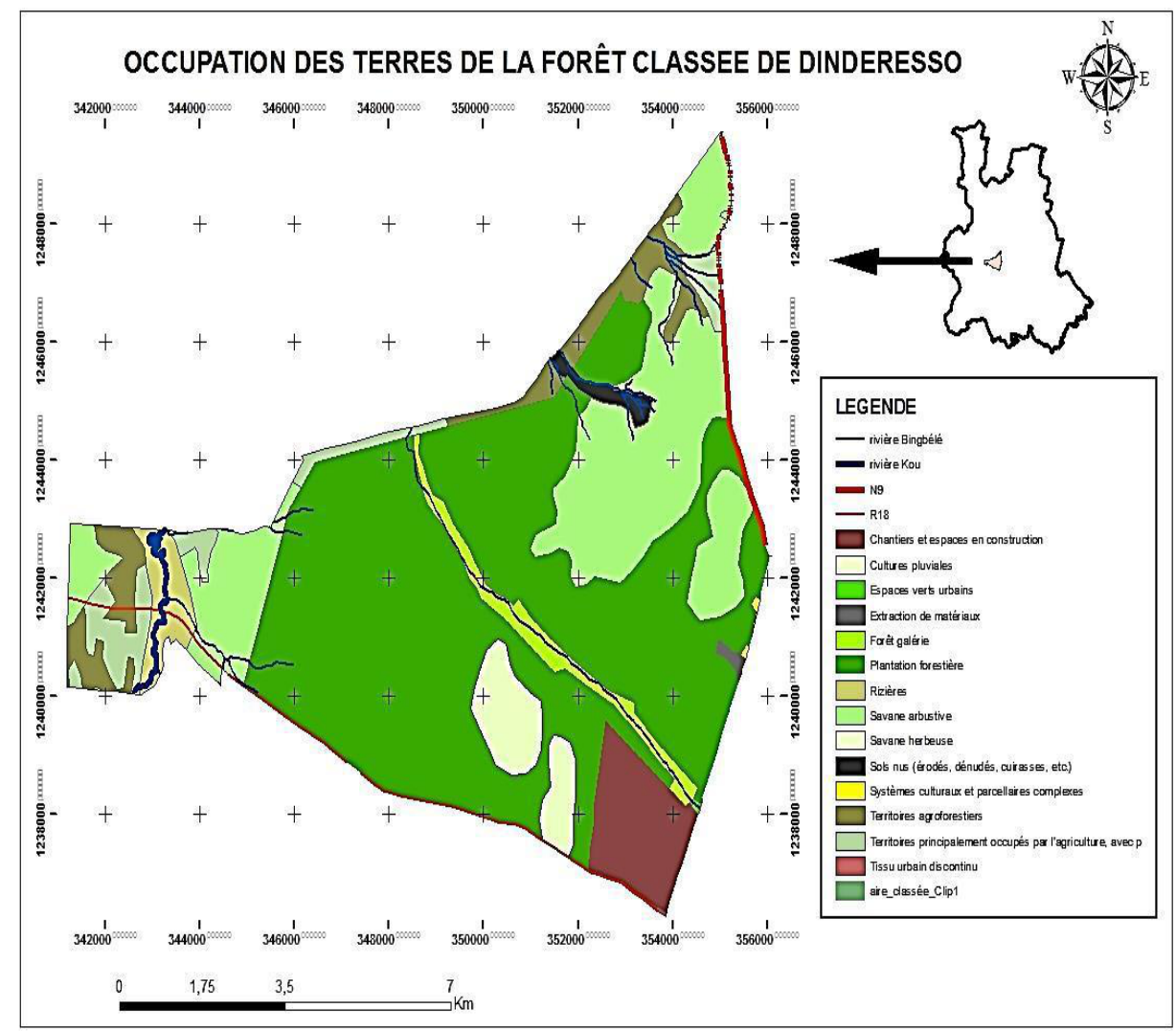

Figure 1: Land occupation of Dindérésso's classified forest (DCF). DCF land use map (Bahiré, 2016)

\section{Antioxidant Activity Determination}

Stock solution of $10 \mathrm{mg} / \mathrm{mL}$ concentration was prepared for various determinations and tests.

DPPH Method: The different stock solutions of the extracts (10 $\mathrm{mg} / \mathrm{mL}$ ) were diluted to the hundredth in methanol to have a test concentration of $100 \mu \mathrm{g} / \mathrm{mL}$. Thus, in three (3) test tubes, $375 \mu \mathrm{L}$ of the diluted solution and $750 \mu \mathrm{L}$ of a DPPH solution $(20 \mathrm{mg} / \mathrm{L})$ were introduced and incubated for $15 \mathrm{~min}$ in the dark. A blank was prepared with $375 \mu \mathrm{L}$ of the sample and $750 \mu \mathrm{L}$ of methanol. Absorbances and concentrations were read with a spectrophotometer (Thermo Fisher, GENESYS 30, Serial number: 9A1W198106) at $517 \mathrm{~nm}$ against a standard $\left(\mathrm{y}=-2.224 \cdot 10^{-2} \mathrm{x}+\right.$ $\left.0.348 ; \mathrm{R}^{2}=0.9966\right)$ obtained from ascorbic acid. The method used is described according to the protocol of Meda et al. (2010). 


\section{Iron (III) to Iron (II) Activity (FRAP)}

The method used is described according to the protocol of Meda et al. (2010). Stock solutions $(10 \mathrm{mg} / \mathrm{mL})$ were diluted to the hundredth in distilled water to give a final test concentration of $100 \mu \mathrm{g} / \mathrm{mL}$. In 3 test tubes, $0.5 \mathrm{~mL}$ of the diluted solution and $0.5 \mathrm{~mL}$ of distilled water were added to another tube for the blank. A volume of $1.25 \mathrm{~mL}$ phosphate buffer $(0.2 \mathrm{M} ; \mathrm{pH}$ 6.6) and $1.25 \mathrm{~mL}$ potassium hexacyanoferrate $\left[\mathrm{K}_{3} \mathrm{Fe}(\mathrm{CN})_{6}\right]$ were added to these tubes. This was heated in a water bath at $50^{\circ} \mathrm{C}$ for $30 \mathrm{~min}$. After this operation, a volume of $1.25 \mathrm{~mL}$ trichloroacetic acid (10\%) was added and the mixture was centrifuged at 3000 revolutions per minute for $10 \mathrm{~min} .0 .625$ $\mathrm{mL}$ of the supernatant were removed from each tube and added to tubes containing $0.625 \mathrm{~mL}$ of distilled water. Freshly prepared trichloroferrate $\left[\mathrm{FeCl}_{3}(0.1 \%)\right] 125 \mu \mathrm{L}$ was added to the resulting mixture. The solution obtained was stirred and then run through a spectrophotometer for a series of three (3) absorbance and concentration readings at a wavelength of $700 \mathrm{~nm}$ against a standard $\left(\mathrm{y}=3.270 .10^{-3} \mathrm{x} ; \mathrm{R}^{2}=0.9990\right)$ established from ascorbic acid.

\section{ABTS Radical Cation Decolorization Assay}

ABTS Method: The method used is described according to the protocol of Coulidiati et al. (2010). For each extract, a methanolic solution $(10 \mathrm{mg} / \mathrm{mL})$ was diluted 100 -fold in distilled water. $10 \mu \mathrm{L}$ of sample (diluted solution) were taken and then mixed with $990 \mu \mathrm{L}$ of the fresh solution from ABTS ${ }^{\bullet+}$. The whole was incubated in the dark for 15 minutes. Absorbances and concentrations were read 3 times at a wavelength of 734 $\mathrm{nm}$ with the spectrophotometer against a standard curve established from ascorbic acid $\left(y=-7.874 .10^{-4} \mathrm{x}+0.709 ; \mathrm{R}^{2}=0.9993\right)$.

\section{Polyphenols Quantification}

Total Phenolics (Bangou et al., 2019): Stock solutions were diluted $1 / 100$ with distilled water to a concentration of $100 \mu \mathrm{g} / \mathrm{mL} .0 .125 \mathrm{~mL}$ of this solution was taken and $0.625 \mathrm{~mL}$ of follicle reagent were added. After $5 \mathrm{~min}$, $0.5 \mathrm{~mL}$ of sodium carbonate were added and incubated for $2 \mathrm{~h}$ in the dark. The blank was prepared with $0.125 \mathrm{~mL}$ of distilled water. Measurement was made with the spectrometer.

Total Flavonoids (Bangou et al., 2019): We used the same dilution principle to obtain a final concentration of $100 \mu \mathrm{g} / \mathrm{mL}$. A total of 4 tubes were prepared into which a volume of $375 \mu \mathrm{L}$ of the diluted solution of each sample was introduced. We added to the first three tubes $750 \mu \mathrm{L}$ of $\mathrm{AlCl}_{3}$, and it was incubated for $10 \mathrm{~min}$ in the dark. The 4th tube considered as a control received $750 \mu \mathrm{L}$ of methanol. 


\section{Data Analysis}

All of the data collected was entered in the Microsoft Excel spreadsheet version 2013, which was also used to calculate the different parameter values.

Ethnobotanical Study: The frequency of citation $(\mathrm{Fc})$ of each plant was determined by the following formula:

$$
F c=\frac{N c}{N t} \times 100
$$

Nc: number of citations of the plant considered and Nt: total number of people surveyed.

Availability Study: In addition to the Excel software, The XLSAT software version 2007 made it possible to make the various analysis to be specific to this activity. The following parameters, used to analyze the structure of the species, were calculated via Excel:

- The density (D), in individuals/ha, of each species for each plant formation:

$$
D=n / s
$$

- $\mathrm{n}$ : number of individuals of the species considered; s: surface of the plot in ha.The mean diameter (DM) of each species for each plant formation:

$$
D M=\frac{\sum_{t=1}^{t} d i}{T}
$$

With di: the diameter of the tree measured at $1.30 \mathrm{~m}$ from the ground and $\mathrm{T}$ : the total number of individuals of the species.

- The basal area $(\mathrm{G})$ of each species for each plant formation $\mathrm{G}=\left(\boldsymbol{\pi} \boldsymbol{d} \boldsymbol{i}^{2} / \mathbf{4}\right)$.

With di: the diameter of the tree measured at $1.30 \mathrm{~m}$ from the ground.

To establish the distribution in class intervals, all individuals of the inventoried species were collected in five (5) class intervals with a diameter of $5 \mathrm{~cm}$ ([5-10]; [10.1-15]; [15.1-20]; [20.1-25] and >25 cm).

The subdivision of the juvenile population into height classes highlights the problem of the development of woody species (Steven, 1984). To this end, the demographic structure of the juvenile population in the regeneration stratum was analyzed on the basis of height classes: [0-0.5]; [0.51-1]; [1.1-1.5]; [1.51-2]; and >2 m.

The availability of the species used was assessed on the basis of surveys carried out on 40 plots. For this purpose, a Rarity-weighted Richness Index was calculated according to the equation: 


$$
R I=\left[1-\left(\frac{n i}{N}\right)\right] \times 100
$$

With RI: the rarity index, ni: number of records in which species $i$ is present, and N: total number of records.

Rarity classes are constituted using the scale proposed by Traoré et al. (2011).

$\mathrm{RI}<60 \%$ : Very frequent species in the plant formation.

$60 \leq \mathrm{RI}<80 \%$ : Medium-frequency species in plant formation.

$\mathrm{RI} \geq 80 \%$ : Rare species in plant formation.

\section{Results and Discussion}

Ethnobotanical Study: A total of 111 people from 11 ethnic groups (bobo, dioula, mossi, San, wolfo, tiéfo, dafi, senoufo, bissa, dogosè, and toussian) were interviewed. The youngest in the field had 10 years of experience and the oldest had 60 years of experience (Table I). Both sexes were represented with approximately the same degree, i.e., $52 \%$ against $48 \%$ for the female sex. The similarity of the proportions of the two genders is explained by the fact that the majority of herbalists were women, who most often settle in the market place. Thus, this is a group we have taken into account in this study. They belonged to different ethnic groups, of which the most represented were the bobos (26\%), the dioulas (23.5\%), and the mossis $(17 \%)$. The ethnobotanical survey also identified 40 species that were used in the treatment of hepatitis in Bobo-Dioulasso. These species were distributed among 23 botanical families (Table II). Table II presents these species, their parts used, and how they are used. The use of these species for this care would mean that these species possess biological activities, specifically antioxidant, antiviral, and hepatoprotective activities. The most represented botanical families are Combretaceae (15\%), Mimosaceae (13\%), and Caesalpiniaceae (10\%). Depending on the group surveyed, different species have been identified with citation frequencies that differ from one group to another (Figure 2). From this figure, it appears that the species Combretum micranthum and Entada africana are regularly cited. Indeed, out of the four groups surveyed, all three cited these two species, compared to the other species that are cited by one or two groups. This could mean that these two species are commonly the most used in the treatment of hepatitis in BoboDioulasso. Furthermore, their use in traditional medicine in the treatment of hepatitis is reported in various studies in Burkina Faso, Mali, Benin, and Africa in general (Bitsindou et al., 1993; Sangaré, 2005; Bangou et al., 2011; Sangaré et al., 2012; Guinnin et al., 2015). This guided our choice of these species for the two other activities of the study, namely: the availability study and phytochemical analysis. 
Table I: Overall socio-demographic characteristics of respondents

\begin{tabular}{llll}
\hline Variable & Categories & Staff & $\begin{array}{l}\text { percentage } \\
(\%)\end{array}$ \\
\hline \multirow{2}{*}{ Genre } & Man & 58 & 52 \\
& Woman & 53 & 48 \\
\hline \multirow{4}{*}{ number of years' experience } & {$[10-20]$} & 80 & 72 \\
& ] $20-30]$ & 16 & 14 \\
& ]30-40] & 11 & 10 \\
& ]40-50] & 2 & 2 \\
& ]50-60] & 2 & 2 \\
\hline \multirow{4}{*}{ ethnic groups } & Bissa & 4 & 4 \\
& Bobo & 29 & 26 \\
& Dafi & 7 & 6 \\
& Dioula & 26 & 23,5 \\
& Dogosè & 5 & 4,5 \\
& Mossi & 19 & 17 \\
& Samoa & 5 & 4,5 \\
& Senoufo & 7 & 6 \\
& Tiéfo & 5 & 4,5 \\
& Toussian & 2 & 2 \\
& Wolfo & 2 & 2 \\
& & &
\end{tabular}

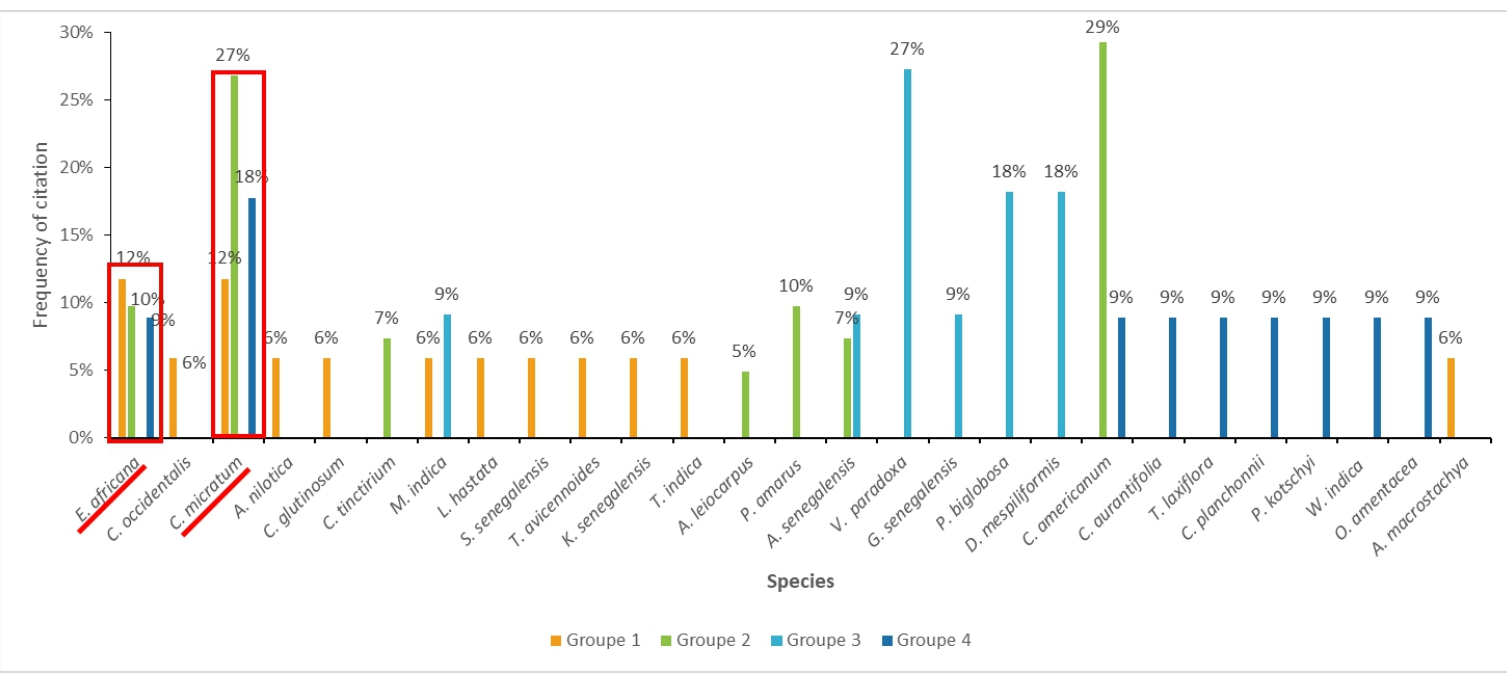

Figure 2 : Frequency of citation of species used in the treatment of hepatitis in BoboDioulasso

As for the used parts of the plants, the leaves were the most commonly used (36\%), followed by the bark of the trunk $(23 \%)$, the roots 
(23\%), and fruits (10\%) (Figure 3). The used parts of C. micranthum and E. africana were mainly the roots. This could mean that it is their roots that possess the hepatoprotective power sought in these plants. However, the removal of these organs represents a danger to the survival of these species. Indeed, the woody plants that intervene in health care through organs such as bark and roots are doomed to disappear because of bad harvesting practices (Bognounou et al., 2009). It is therefore imperative to find alternatives to limit the exploitation of these organs, with a view to sustainable management of these species.

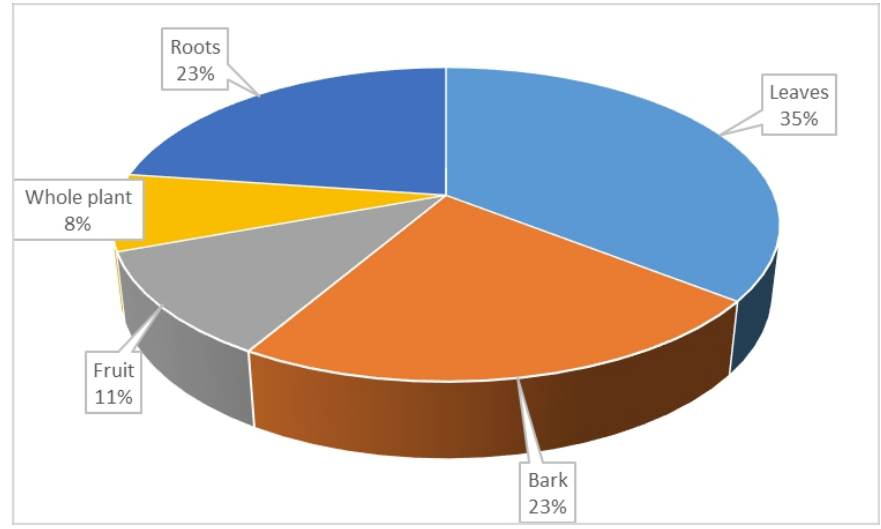

Figure 3 : Proportion of plant parts used

\section{Availability Study}

Species Abundance: Table III shows the densities obtained in adult and juvenile stands of E. africana and $C$. micranthum in the different plant formations. In general, the adult stand of E. africana was relatively denser in the grassy savannah with 107 individuals/ha and that of $C$. micranthum was densely represented in the wooded savannah with 56 individuals/ha. As for the density of the juvenile stand, the juvenile feet of E. africana were densely present in wooded and grassy savannah with 373 and 429 individuals/ha respectively for each plant formation. For that of $C$. micranthum, juvenile individuals were densely present in wooded savannah with 1941 individuals/ha. Hence, these two species are not present in gallery forests.

Table II : List of medicinal species identified in the ethnobotanical survey for the treatment of hepatitis

\begin{tabular}{|c|c|c|c|c|}
\hline Family & Species & $\begin{array}{l}\text { Used } \\
\text { parts }\end{array}$ & $\begin{array}{l}\text { Mode of } \\
\text { preparation }\end{array}$ & $\begin{array}{l}\text { Mode of } \\
\text { administration }\end{array}$ \\
\hline \multirow[t]{3}{*}{ Anacardiaceae } & Mangifera indica $\mathrm{L}$. & Leaves & \multirow[t]{3}{*}{ Decoction } & Oral use \\
\hline & Sclerocarya birrea A. Rich) Hochst & Bark & & Drink; Bath \\
\hline & $\begin{array}{l}\text { Lannea microcarpa Engl. et } \mathrm{K} \text {. } \\
\text { Krause }\end{array}$ & & & Oral use \\
\hline Annonaceae) & Annona senegalensis Pers. & Leaves & Decoction & Oral use \\
\hline
\end{tabular}




\begin{tabular}{|c|c|c|c|c|}
\hline Apocynaceae & Saba senegalensis (A. DC.) Pichon & Fruit & Powder & \\
\hline Asclepiadaceae & Leptadenia hastata (Pers), Decne. & Leaf root & Decoction & \\
\hline Asteraceae & Chrysanthellum indicum DC. & $\begin{array}{l}\text { Whole } \\
\text { Plant }\end{array}$ & Infusion & \\
\hline Bombacaceae & Adansonia digitata $\mathrm{L}$. & Bark & Powder & \\
\hline Burseraceae & $\begin{array}{l}\text { Commiphora africana (A. Rich.) } \\
\text { Engl. }\end{array}$ & Leaves & Decoction & \\
\hline \multirow[t]{4}{*}{ Caesalpiniaceae } & $\begin{array}{l}\text { Detarium microcarpum Guill et } \\
\text { Perr. }\end{array}$ & Bark & $\begin{array}{l}\text { Decoction, } \\
\text { Powder }\end{array}$ & \multirow[t]{4}{*}{ Oral use } \\
\hline & Swartzia madagascariancis Desv. & Roots & \multirow[t]{2}{*}{ Powder } & \\
\hline & Cassia occidentalis $\mathrm{L}$. & Leaves & & \\
\hline & Tamarindus indica $\mathrm{L}$. & Roots & Decoction & \\
\hline Caricaceae & Carica papaya $\mathrm{L}$. & Fruit & Decoction & \multirow[t]{3}{*}{ Oral use } \\
\hline \multirow[t]{2}{*}{ Cochlospermaceae } & $\begin{array}{l}\text { Conchlospermum tinctirium Perr. } \\
\text { Ex A. Rich. }\end{array}$ & \multirow[t]{2}{*}{ Roots } & \multirow[t]{2}{*}{$\begin{array}{l}\text { Decoction, } \\
\text { Powder }\end{array}$} & \\
\hline & Cochlospermum planchonnii & & & \\
\hline \multirow[t]{6}{*}{ Combretaceae } & Combretum micrantum G. Don & Roots & $\begin{array}{l}\text { Decoction } \\
\text { Powder }\end{array}$ & \multirow[t]{2}{*}{ Oral use } \\
\hline & $\begin{array}{l}\text { Combretum glutinosum Perr. ex } \\
\text { DC. }\end{array}$ & $\begin{array}{l}\text { Whole } \\
\text { Plant }\end{array}$ & Powder & \\
\hline & $\begin{array}{l}\text { Anogeissus leiocarpus (DC.) Guill. } \\
\& \text { Perr. }\end{array}$ & Leaves & Decoction & $\begin{array}{l}\text { Oral bath ; Seat } \\
\text { bath }\end{array}$ \\
\hline & Guiera senegalensis J. F. Gmel. & Roots & $\begin{array}{l}\text { Infusion of } \\
\text { Powder }\end{array}$ & Oral use \\
\hline & Terminalia laxiflora Engl. & & Decoction & \\
\hline & $\begin{array}{l}\text { Terminalia avicennoides Guill. et } \\
\text { Perr. }\end{array}$ & Bark & $\begin{array}{l}\text { Decoction } \\
\text { Infusion }\end{array}$ & \\
\hline Euphorbiaceae & $\begin{array}{l}\text { Philantus amarus Shumach. et } \\
\text { Thonn. }\end{array}$ & $\begin{array}{l}\text { Whole } \\
\text { Plant }\end{array}$ & $\begin{array}{l}\text { Decoction, } \\
\text { Powder }\end{array}$ & Oral use \\
\hline Ebenaceae & $\begin{array}{l}\text { Diospyros mespiliformis Hochst. ex } \\
\text { A. DC }\end{array}$ & Bark & $\begin{array}{l}\text { Powder } \\
\text { Infusion }\end{array}$ & \\
\hline Fabaceae & Pterocarpus lucens Gull et Perr & Roots & Decoction & \\
\hline Meliaceae & Khaya senegalensis (Desr.) A. Juss. & Bark & & \\
\hline Meliaceae & $\begin{array}{l}\text { Pseudocedrela } \\
\text { (Schweinf.) Harms }\end{array}$ & & & \\
\hline \multirow[t]{5}{*}{ Mimosaceae } & Entada africana Guill. et Perr. & Roots & $\begin{array}{l}\text { Decoction, } \\
\text { Powder }\end{array}$ & \\
\hline & Acasia nilotica (L) Willd. ex Del. & Seeds & Decoction & \\
\hline & $\begin{array}{l}\text { Parkia biglobosa (Jacq.) R. ex G. } \\
\text { Don }\end{array}$ & \multirow[t]{2}{*}{ Bark } & Infusion & \\
\hline & $\begin{array}{l}\text { Prosopis africana Guill. Perr. et } \\
\text { Rich. }\end{array}$ & & \multirow[t]{2}{*}{ Decoction } & \\
\hline & $\begin{array}{l}\text { Accacia macrostachya Reichenb. } \\
\text { ex Oc. }\end{array}$ & Leaves & & \\
\hline Lamiaceae & Hyptis spicigera Lam. & \multirow[t]{4}{*}{ Leaves } & \multirow[t]{4}{*}{ Decoction } & \multirow[t]{4}{*}{ Oral use } \\
\hline Opiliaceae & $\begin{array}{l}\text { Opilia amentacea (Guili. et Perr) } \\
\text { Endl. ex Walp. }\end{array}$ & & & \\
\hline Palmae & Hyphaena thebaica (L.) Mart. & & & \\
\hline Poaceae & Oxytenanthera abyssina (A. Rich.) & & & \\
\hline
\end{tabular}




\begin{tabular}{|c|c|c|c|}
\hline & Munro & & \\
\hline Rutaceae & $\begin{array}{l}\text { Citrus aurantifolia (Chnstm.) } \\
\text { SWingle }\end{array}$ & Fruit & Infusion \\
\hline Sapotaceae & Vitellaria paradoxa C. F. Gaertn. & Leaves & $\begin{array}{l}\text { Powder } \\
\text { Infusion }\end{array}$ \\
\hline \multirow[t]{2}{*}{ Sterculiaceae } & Sterculia setigera Del. & & Decoction \\
\hline & Walteria indica $\mathrm{L}$. & $\begin{array}{l}\text { Whole } \\
\text { Plant }\end{array}$ & \\
\hline
\end{tabular}

Table III: Density of adult and juvenile individuals of both species

\begin{tabular}{lllll}
\hline \multirow{2}{*}{ plant formation type } & \multicolumn{2}{l}{ Entada africana } & \multicolumn{2}{l}{ Combretum micranthum } \\
\cline { 2 - 5 } & $\begin{array}{l}\text { Number of Number } \\
\text { adult plants / juvenile plants / } \\
\text { ha }\end{array}$ & $\begin{array}{l}\text { of } \\
\text { ha }\end{array}$ & $\begin{array}{l}\text { Number of } \\
\text { adult plants / } \\
\text { ha }\end{array}$ & $\begin{array}{l}\text { Number } \\
\text { juvenile plants / ha }\end{array}$ \\
\hline Forest gallery & 00.00 & 00.00 & 00.00 & 00.00 \\
Wooded savannah & 66.70 & 373.33 & 56.30 & 1941.33 \\
Shrubby savannah & 25.93 & 186.67 & 4.94 & 355.56 \\
Grassy savannah & 107.07 & 429.09 & 5.05 & 123.64 \\
\hline
\end{tabular}

Rarity Index of Adult Species: Rarity indices (Table IV) revealed that adult individuals of $E$. africana were very common in wooded (RI=27\%), shrubby $(\mathrm{RI}=44 \%)$, and grassy $(\mathrm{RI}=9 \%)$ savannahs. As for those of $C$. micranthum, they were very frequent only in wooded savannah (RI=47\%). As for the juvenile stratum, Table $\mathrm{V}$ shows that juvenile individuals of $E$. africana were very frequent in grassy savannahs $(\mathrm{RI}=55 \%)$ and moderately frequent in wooded $(\mathrm{RI}=60 \%)$ and shrubby $(\mathrm{RI}=70 \%)$ savannahs, while those of $C$. micranthum were only very frequent in wooded savannahs (RI=50\%) (Table IV).

Table IV: Frequencies and Rarity indices of adult individuals of the two species

\begin{tabular}{llllll}
\hline \multirow{3}{*}{ Formation } & Entada africana & \multicolumn{3}{l}{ Combretum micranthum } \\
\cline { 2 - 7 } & $\begin{array}{l}\text { Frequency } \\
(\%)\end{array}$ & $\begin{array}{l}\text { Rarity } \\
(\%)\end{array}$ & $\begin{array}{l}\text { Index } \\
\text { Frequency } \\
(\%)\end{array}$ & $\begin{array}{l}\text { Rarity } \\
(\%)\end{array}$ & Index \\
\hline Forest gallery & 0 & 100 & 0 & 100 & \\
Wooded savannah & 73 & 27 & 53 & 47 \\
Shrubby savannah & 56 & 44 & 11 & 89
\end{tabular}

Table V: Frequencies and Rarity indices of juvenal individuals of the two species

\begin{tabular}{llllll}
\hline \multirow{2}{*}{ Formation } & Entada africana & & \multicolumn{2}{l}{ Combretum micranthum } \\
\cline { 2 - 6 } & $\begin{array}{l}\text { Frequency } \\
(\%)\end{array}$ & $\begin{array}{l}\text { Rarity } \\
(\%)\end{array}$ & $\begin{array}{l}\text { Index } \\
\text { Frequency } \\
(\%)\end{array}$ & $\begin{array}{l}\text { Rarity } \\
(\%)\end{array}$ \\
\hline Forest gallery & 0 & 100 & 0 & 100 \\
Wooded savannah & 40 & 60 & 50 & 50 \\
Shrubby savannah & 30 & 70 & 10 & 90 \\
Grassy savannah & 45 & 55 & 10 & 90 \\
\hline Grassy savannah & 91 & 9 & 9 & 91 \\
\hline
\end{tabular}


Analysis of these different parameters show that adult and juvenile individuals of E. africana were denser in the grassy savannah, with 107 and 429 individuals/ha respectively, when compared to the other plant formations of the Dindérésso Classified Forest. It is therefore easier to find those species in the said formation. Its absence in gallery forests could be explained by its ecology. Concerning $C$. micranthum, adult and juvenile individuals were abundant in the wooded savannah. Considering the average density of juvenile individuals higher than that of adult individuals, both species had a good regeneration capacity in the two plant formations indicated (Taïa, 1997). This good regeneration of these species should ensure the recruitment of juveniles in the different successive height classes. This good regeneration capacity could be explained by the fact that these species find favorable conditions for their development, such as soil types.

\section{Structural Characterization of Populations}

The adult stand structure of the species shows a predominance of small individuals for both species. Indeed, whatever the type of formation concerned, the individuals are included in the classes $[5 ; 10][10.1 ; 15]$ (Figure 4 and Figure 5).

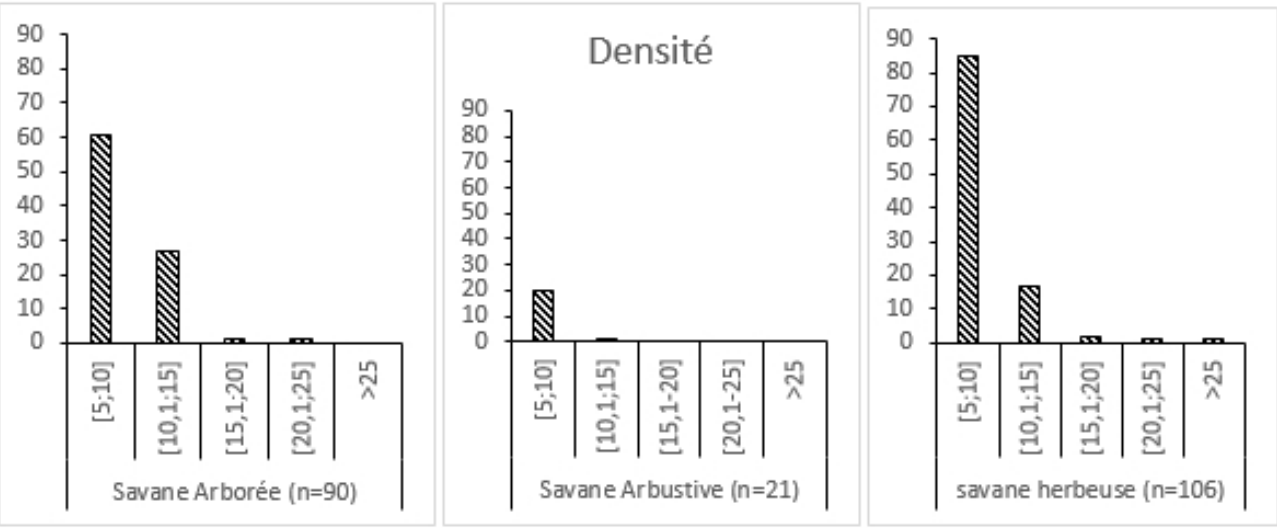

Figure 4: Diameter class structure of adult individuals of E. africana in (A) woody savannah, (B) shrubby savannah and (C) grassy savannah. 


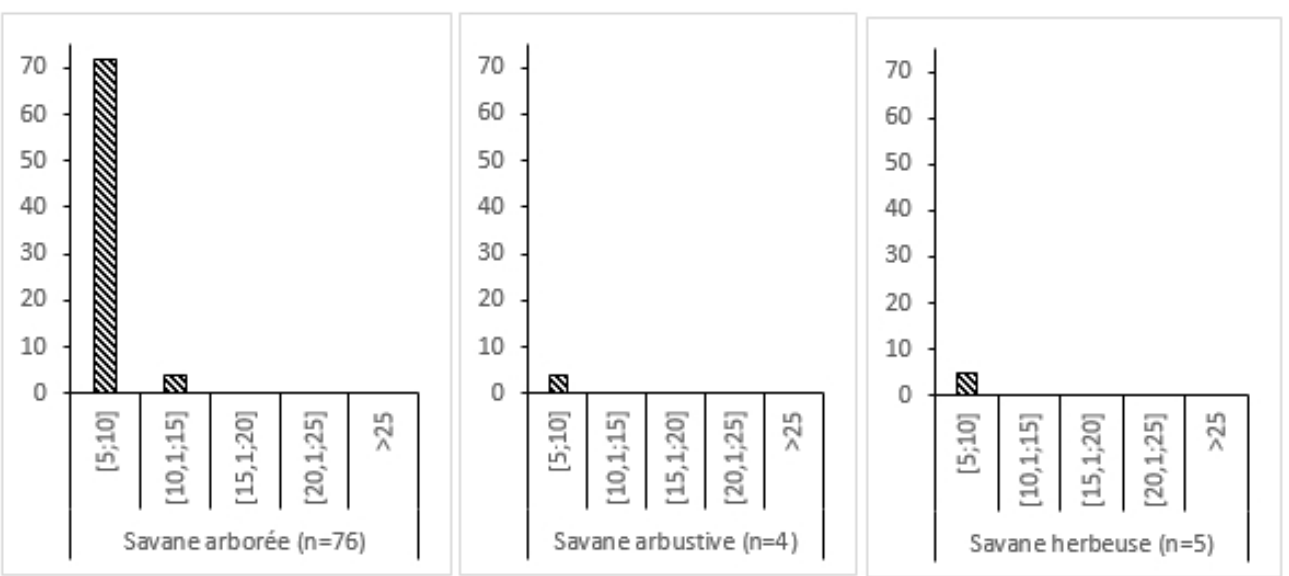

Figure 5: Diameter class structure of adult's individuals of $C$. micranthum in (A) woody savannah, (B) shrubby savannah and (C) grassy savannah.

The height class structure of juvenile individuals of E. africana reveals the presence of individuals in all height classes in the woody and grassy savannah (Figure 6). Also, C. micranthum reveals the presence of individuals in all height classes in the woody savannah (Figure 7).

Species diameter class structures showed a predominance of small size individuals for both species. Indeed, the number of individuals is higher in the smaller diameter classes. This predominance of small-diameter individuals in the stands of both species could be explained by the fact that these are shrubs generally dominated by small-diameter individuals. Also, this predominance would characterize a stable population of these species if regular recruitment of the juvenile population in the various successive diameter classes could be ensured. Unfortunately, the structure of the juvenile populations of both species appears unstable. In fact, a low presence or absence of individuals in some height classes has been observed, indicating a low or irregular recruitment from the juvenile to the adult stratum. This could be due to anthropogenic pressures such as bush fires and methods of collection for their use in traditional medicine. The irregular recruitment of juveniles to the adult stratum suggests that populations of both species are declining, and their continued exploitation would be a threat to their survival. Specifically, the exploitation of their roots in the treatment of the hepatitis concerned in the present study may even lead to the disappearance of these species (Bognounou et al., 2009). Alternatives should therefore be considered to reconcile the preservation of medicinal species and traditional medicinal needs. One approach could be the planting and assisted regeneration of medicinal species. However, this technique presents weaknesses when the pressure is high, beyond the development capacity of 
these species. Also, knowledge of the phytochemistry of these species could be exploited to limit root harvesting.

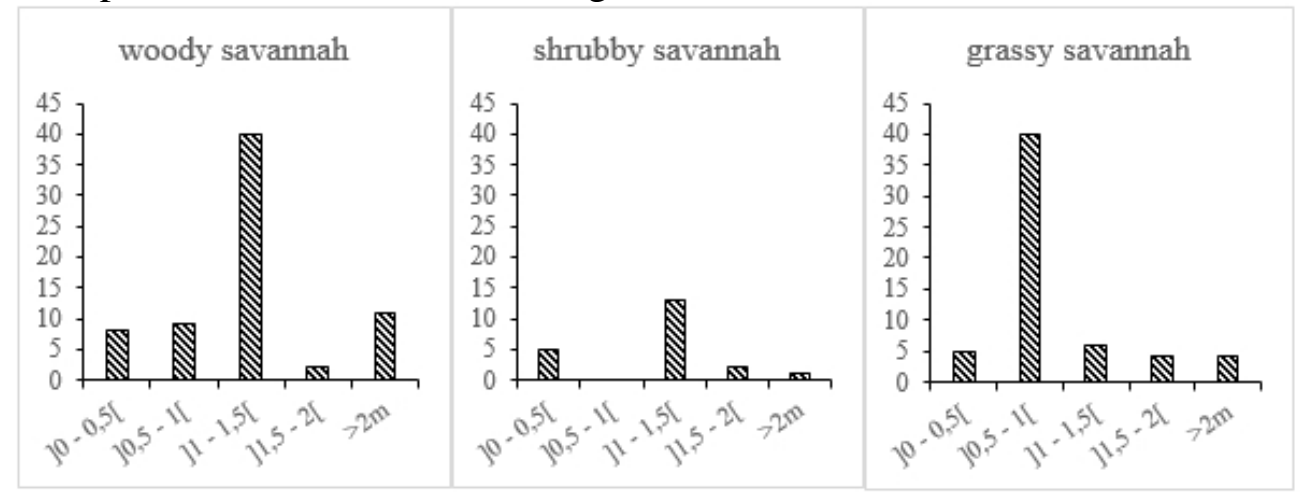

Figure 6: Height class structure of juvenile individuals of E. africana in woody savannah, shrubby savannah and grassy savannah.

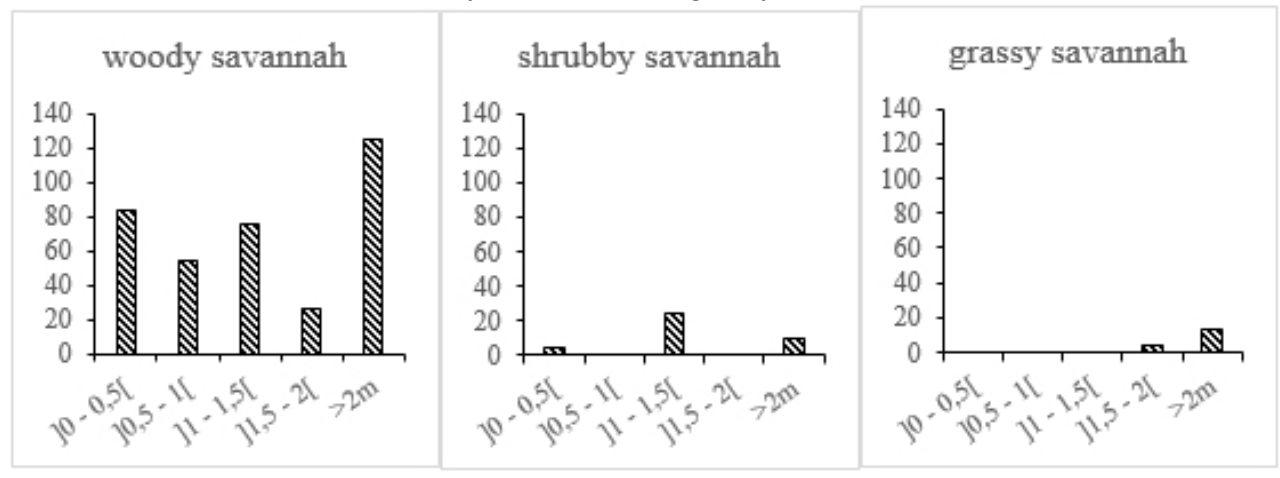

Figure 7: Height class structure of juvenile individuals of $C$. micranthum in woody savannah, shrubby savannah and grassy savannah.

In addition, other investigations could be carried out on the architecture of the root system of these species because, according to Kaboré (2015), the knowledge of such architecture of the species whose roots are harvested could result to good harvesting practices that would minimize the destruction of the latter.

\section{Phytochemical Analysis}

Determination of Total Polyphenols: The results of the determinations are shown in Table VI. Total phenolics contents were 20.70 $\pm 0.24 \mathrm{mg}$ EAG/100mg extract for E. africana and $37.91 \pm 1.30 \mathrm{mg}$ EAG/100mg extract for $C$. micranthum. The best content was obtained by $C$. micranthum which was $37.91 \pm 1.30$. For total flavonoids, the contents were $0.66 \pm 0.04$ and $0.87 \pm 0.09 \mathrm{mg} \mathrm{EQ} / 100 \mathrm{mg}$ extract for $E$. africana and $C$. micranthum respectively. 
Table VI: Content of total polyphenols and flavonoids

\begin{tabular}{lll}
\hline Species & $\begin{array}{l}\text { Total Polyphenols } \\
\text { (mg EAG/100mg extract) }\end{array}$ & $\begin{array}{l}\text { Total Flavonoids } \\
\text { (mg EQ/100mg extract) }\end{array}$ \\
\hline Combretum micranthum & $37.91 \pm 1,30$ & $0,85 \pm 0.09$ \\
Entada africana & $20.71 \pm 0,25$ & $0.66 \pm 0.05$ \\
\hline
\end{tabular}

Assessment of Antioxidant Activity: These results are recorded in Table VII. Indeed, we obtained a value of 198.54 $\pm 3.66,13.58 \pm 0.36$ and $14.88 \pm 0.17 \mu \mathrm{mol}$ EAA respectively with the ABTS, DPPH and FRAP methods for $C$. micranthum species. For the species $E$. africana, the values were $197.27 \pm 1.47,13.70 \pm 0.07$ and $18.84 \pm 1.23 \mu \mathrm{mol}$ EAA by using the ABTS, DPPH and FRAP methods, respectively.

Table VII: Results of ABTS, DPPH and FRAP methods

\begin{tabular}{llll}
\hline Species & $\begin{array}{l}\text { ABTS } \\
(\mu \mathrm{mol} \mathrm{EAA})\end{array}$ & $\begin{array}{l}\text { DPPH } \\
(\mu \mathrm{mol} \text { EAA })\end{array}$ & $\begin{array}{l}\text { FRAP } \\
(\mu \mathrm{mol} \text { EAA })\end{array}$ \\
\hline Combretum micranthum & $198.54 \pm 3.66$ & $13.58 \pm 0.36$ & $14.88 \pm 0.17$ \\
Entada africana & $197.27 \pm 1.47$ & $13.70 \pm 0.07$ & $18.84 \pm 1.23$ \\
\hline
\end{tabular}

The Soxhlet methanolic extraction yield of $C$. micranthum was $6.90 \%$ and that of E. africana $8.87 \%$. The contents of total phenolics and flavonoids were respectively $37.91 \pm 1.30 \mathrm{mg}$ EAG/100mg extract and $0.85 \pm$ $0.09 \mathrm{mg} \mathrm{EQ} / 100 \mathrm{mg}$ for C. micranthum. For E. africana species, we obtained $20.70 \pm 0.24 \mathrm{mg}$ EAG $/ 100 \mathrm{mg}$ total phenolics extract and $0.66 \pm 0.05 \mathrm{mg}$ $\mathrm{EQ} / 100 \mathrm{mg}$ total flavonoids extract. The latter values were slightly lower than those obtained from $C$. micranthum extracts. Total polyphenols were therefore present in the root extracts of the two species in the study. These compounds could probably be responsible for the antiviral and hepatoprotective activities attributed to these species. Indeed, it is these compounds that possess such properties in plants.

Evaluation of antioxidant activities by three complementary methods, ABTS, DPPH and FRAP, yielded significant values for each method. These values were approximately the same for both species. This could mean that C. micranthum and E. africana do possess antioxidant activities. The antioxidant activity of a plant extract is of particular interest. It corresponds to the capacity of the extract to protect the organism against oxidative stress damage, which is involved in the induction and amplification of various pathologies, such as liver diseases. The presence of these secondary metabolites and their associated pharmacological properties in these species would be a reason for their use in the care of hepatitis. Their roots are therefore collected in order to research the pharmacological properties of these metabolites. Thus, the knowledge of the phytochemistry of these species could be used to limit root harvesting. Indeed, previous investigations (Bangou et al., 2011; Kwaji, 2017; Kwaji et al., 2018) have 
revealed that the leafy twigs of $C$. micranthum and the trunk bark of $E$. africana would have the same properties as those obtained in the root extracts of these two species in the present study. Such comparative analysis could provide strong arguments for orienting the population towards the use of other parts of these species whose harvesting will compromise less the sustainability of these species.

\section{Conclusion}

This study showed that the ethnobotanical survey conducted among traditional practitioners in Bobo-Dioulasso revealed that a diversity of medicinal plants was used in the treatment of hepatitis in this region of Burkina Faso. The survey identified 40 species belonging to 23 botanical families used in the treatment of these dreaded diseases. Citation frequencies also revealed that Combretum micranthum and Entada africana were regularly cited and were thus the subject of a phytochemical study. This phytochemical study showed that these two species possess antioxidant properties. The structure of the adult populations showed a predominance of small individuals for both species. An overall analysis of the adult and juvenile strata leads to the conclusion that the populations of these two species are declining due to anthropogenic pressure. Furthermore, their exploitation must therefore be appropriate for their effective conservation and preservation.

Our next studies on these plants' species will aim at making a bioguided evaluation to (1) identify the polyphenolic compounds implied in the hepatoprotective activity in vivo, (2) to check literatures informations such as anti-inflammatory and cyto-toxicity properties for the extend purpose of this type of inventory to other regions of Burkina Faso.

\section{Acknowledgements}

The authors thank The International Atomic Energy Agency (IAEA) for its financial assistance to the projects $\mathrm{N}^{\circ} \mathrm{BKF} 5021$ awarded to Doctor Roland N-T Meda. The authors are grateful to Abdoul Kader Zangré -water and forests inspectors-for providing us access to the Traditional Healers Association of Bobo-Dioulasso.

\section{References:}

1. AFRAVIH (2018). Appel de Bordeaux en faveur de la lutte contre les hépatites virales $B$ et $C$, Conférence internationale Francophone, 1-4. https://www.ird.fr/lird-partenaire-de-la-9eme-conference-afravih2018

2. Arbonnier, M. (2000). Arbres, arbustes et lianes des zones sèches d'Afrique de l'Ouest. ISBN CIRAD 2-87614-431-X, 525p. 
3. Bangou, M.J., Coulidiati, H.T., Meda, R.N-T., Reyes-Martinez, A., Torres-Morán, M.I., Arellano-Candia, Z., Gallegos, H.O., Nacoulma, O.G. \& Ouedraogo, A.G. (2019). Polyphenols profile and antioxidants capacity of Verbenaceae species from Burkina Faso. Int. J. of Pharm. Life Sci., 10(4): 6104-6128.

http://www.ijplsjournal.com/April-2019.html

4. Bangou, M.J., Kiendrebeogo, M., Compaoré, M., Coulibaly, A.Y., Meda, R.N-T. \& Almaraz-Abarca, N. (2011). Enzyme inhibition effect and polyphenols content of plant extracts from Burkina Faso, Journal of biological sciences, 11 (1) 31-38.

https://scialert.net/abstract/?doi=jbs.2011.31.38

5. Bitsindou, M., Lejoly, J. \& Van, E. (1993). Laboratoire de Botanique systématique et de Phytosociologie Université Libre de Bruxelles. Les plantes employées contre les affections hépatiques en médecine traditionnelle africaine, Colloque Européen d'Ethnopharmacologie et de la 11ème conférence internationale d'Ethnomédecine, Heidelberg $\mathrm{p}$ 163-169. http://horizon.documentation.ird.fr/exldoc/pleins_textes/pleins_textes_6/colloques2/010005533.pdf

6. Bognounou, F., Thiombiano, A., Savadogo, P., Boussim, J.I., Odén, P.C. \& Guinko, S. (2009). Woody vegetation structure and composition at four sites along latitudinal gradient in Western Burkina Faso. Bois et Forêt des Tropiques, 300 (2): 29-44. https://pdfs.semanticscholar.org/d123/243f153dace4dbea0373b5a96a e9fb4b41f8.pdf

7. CAPES (Centre for Economic and Social Policy Analysis) (2004). Analyse situationnelle dans quatre régions du Burkina Faso : Cascades, Hauts-Bassins, Sahel et Sud-Ouest. Rapport final. CAPES; 241p. https://www.capes.bf/spip.php?page=plan

8. Coulidiati, H.T. (2010). Phytochimie et activités biologiques $\mathrm{d}^{\text {ee }}$ extraits de trios (3) Espèces de Combretaceae du Burkina Faso: Combretum acutum Laws; Combretum nioroens Aubrex. Ex Keay et Combretum sericeum G. Don. Thèse unique de doctorat, 148p. http://www.beep.ird.fr/collect/uouaga/index/assoc/M12850.dir/M128 50.pdf

9. Guinnin, F., Sacramento, T.I., Sezan, A. \& Ategbo, J. (2015). Etude Ethnobotanique des plantes médicinales utilisées dans le traitement traditionnel des hépatites virales $\mathrm{B}$ et $\mathrm{C}$ dans quelques départements du Bénin, International Journal of Biological and Chemical Sciences 9 (3): 1354-1366.

https://www.ajol.info/index.php/ijbcs/article/view/121734

10. Kaboré, S.A. (2015). Évaluation des services écosystémiques de Crateva adansonii D.C., Sarcocephalus latifolius (Smith) Bruce et 
Burkea africana Hook. dans la région du Sud-Ouest du Burkina Faso Thèse de Doctorat, Université Polytechnique de Bobo-Dioulasso, 181p. http://www.beep.ird.fr/collect/upb/index/assoc/IDR-2015KAB-EVA/IDR-2015-KAB-EVA.pdf

11. Kwaji, A. (2017). Phytochemical analysis, antibacterial and antioxidant activities of Entada africana Guill. and perrott stem bark extracts, Research Journal of Chemical Sciences, Vol. 7(10), 10-15. http://www.isca.in/rjcs/Archives/v7/i10/2.ISCA-RJCS-2017-068.php

12. Kwaji, A., Adamu, H.M., Chindo, I.Y. \& Atiko, R. (2018). Isolation, characterization and biological properties of betulin from Entada africana Guill. and Perr. (Mimosaceae). Journal of Applied and Advanced Research, 3(1) :28-31.

https://www.researchgate.net/publication/324016087

13. Maydell, H-J Von. (1992). Arbres et arbustes du Sahel: leurs caractéristiques et leurs utilisations. ISBN, 3-8236-1197-6, 516p.

14. Meda, N., Tuaillon, E., Kania, D., Tiendrebeogo, A., Pisoni, A., Zida, S., Bollore, K., Medah, I., Laureillard, D., Moles, J., Nagot, N., Nebié, K., Van de Perre, P. \& Dujols, P. (2018). Hepatitis B and C virus seroprevalence, Burkina Faso: a cross-sectional study, Bull World Organe de la santé $96 \quad$ (11): 750-759. https://www.ncbi.nlm.nih.gov/pmc/articles/PMC6239015

15. Meda, R.N-T., Lamien-Meda, A., Kiendrebeogo, M., Coulibaly, A.Y., Millogo-Rasolodimby, J. \& Nacoulma, O.G. (2010). In vitro Antibacterial, Xanthine Oxidase and Acetylcholinesterase Inhibitory Activities of Balanites aegyptiaca (L.) Del. (Balanitaceae). Pakistan Journal of Biological Sciences, 2010; 13 (8): 362-368. https://scialert.net/abstract/?doi=pjbs.2010.362.368

16. Ouedraogo, O., Thiombiano, A., Hahn-Hadjali, K. \& Guinko, S. (2009). Diversité et dynamique de la végétation ligneuse juvénile du Parc National d'Arly (Burkina Faso). Candollea 64(2): 257-278. https://www.researchgate.net/publication/257539920

17. Sangaré, O. (2005). Evaluation de Cochlospermum tinctorium, Entada africana et Combretum micranthum dans le traitement des hépatites à Bamako. Thèse de Doctorat, Université de Bamako, 148p. http://www.keneya.net/fmpos/theses/2006/pharma/pdf/06P20.pdf

18. Sangaré, M.M., Sina, H., Dougnon, J., Bayala, B., Ategbo, J.M. \& Dramane, K.L. (2012). Etude ethnobotanique des plantes hépatotropes et de l'usage traditionnel de Gomphrena celosioides Mart. (Amaranthaceae) au Bénin. International Journal of Biological and Chemical Sciences 6 (6): 5008-5021.

https://www.ajol.info/index.php/ijbcs/article/view/88448 
19. Sop, T.K., Oldeland, J., Schmiedel, U., Ouédraogo, I. \& Thiombiano, A. (2010). Population structure of three woody species in four ethnic domains of the sub-sahel of Burkina Faso. Land Degradation and Development, DOI 10.1002/ldr. 1026. https://onlinelibrary.wiley.com/doi/abs/10.1002/ldr.1026

20. Sourabié, T.S., Nikiéma, J.B., Guissou, I.P. \& Nacoulma, O.G. (2012). Etude comparée des effets antihépatotoxiques d'extraits d'Argemone mexicana L. (Papaveraceae), une plante utilisée dans le traitement traditionnel de la jaunisse au Burkina Faso. International Journal of Biological and Chemical Sciences 6(3): 1139-1147. https://www.semanticscholar.org/paper/Etude-compar\%C3\%A9edes-effets-anti-h\%C3\%A9patotoxiques-d\%E2\%80\%99-L.-SourabieNikiema/2d208f7dc4741640cb8bddd58de99b3846f1f087

21. Steven, D.D. (1984). Tropical tree seedling dynamics: recruitments pattern and their population consequences for three canopy species in Panama. Journal of Tropical Ecology, 10:369-383.

https://www.cambridge.org/core/journals/journal-of-tropicalecology/article/tropical-tree-seedling-dynamics-recruitment-patternsand-their-population-consequences-for-three-canopy-species-inpanama/91A99CB085CA4E94B7DEA2218E31755B

22. Taïta, P. (1997). Contribution à l'étude de la flore et de la végétation de la Réserve de la Biosphère de la Mare aux Hippopotames (Bala, Ouest du Burkina Faso). Thèse Doctorat, Université de Ouagadougou, 201 p. https://www.persee.fr/doc/jatba_01835173_1985_num_32_1_3938

23. Traore, L., Ouédraogo, I., Ouédraogo, A. \& Thiombiano, A. (2011). Perceptions, usages et vulnérabilité des ressources végétales ligneuses dans le Sud-Ouest du Burkina Faso, Int. J. Biol. Chem. Sci. 5(1): 258-278. https://www.researchgate.net/publication/256662480

24. Twedt, D.C. (2006). Nouvelles approches thérapeutiques des affections hépatiques : la SAMe. Pratique médicale \& chirurgicale de l'animal de compagnie, 41(4): 269-272.

25. WGO (2012). Stéatose hépatique non alcoolique et stéato-hépatite non alcoolique. WGO Global Guidelines NAFLD/NASH (long version), 33p.

https://www.chuv.ch/fileadmin/sites/glg/NALFD_Maladie_steatosiqu e_non_alcoolique_du_foie.pdf

26. WHO (2016). Stratégie mondiale du secteur de la santé contre l'hépatite virale, 2016-2021.

https://apps.who.int/iris/bitstream/10665/250577/1/WHO-HIV2016.06-fre.pdf 
27. Yelkouni, M. (2004). Gestion d'une ressource naturelle et action collective : le cas de la forêt de Tiogo au Burkina Faso, Thèse de doctorat, Université d'Auvergne, Clermont Ferrand, France. https://tel.archives-ouvertes.fr/tel-00660993/document

28. Zerbo, P., Millogo-Rasolodimby, J., Nacoulma-Ouédraogo, O.G. \& Van Damme, P. (2007). Contribution à la connaissance des plantes médicinales utilisées dans les soins infantiles en pays San, au Burkina Faso. International Journal. Of Biological and Chemical Sciences, 1(3): 262-274. https://www.researchgate.net/publication/272442118 